\title{
The Local Capacity, Local Community and Local Governance Dimensions of Sustainability in Australian Local Government
}

\section{Commonwealth Journal of Local Governance Issue 8/9: May-November 2011 \\ http://epress.lib.uts.edu.au/ojs/index.php/cjlg}

\section{Brian Dollery ${ }^{[1]}$}

Centre for Local Government

University of New England, Armidale

\section{Lin Crase ${ }^{[2]}$}

Faculty of Law and Management \& Regional School of Business

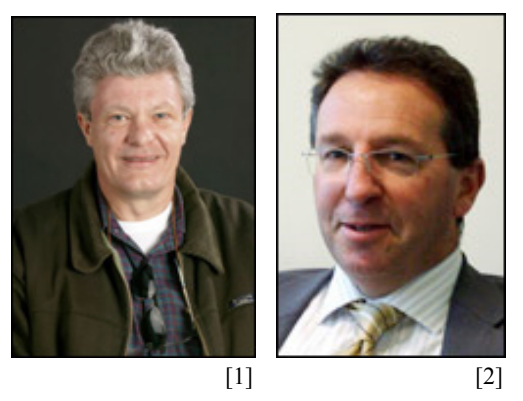

La Trobe University

\section{Bligh Grant ${ }^{[3]}$}

Centre for Local Government

University of New England, Armidale

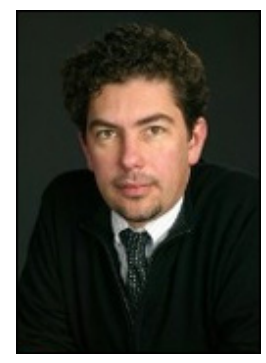

[3]

\section{Introduction}

The problem of the 'financial sustainability' of individual local councils represents the most significant policy question at issue in contemporary debate on Australian local government. This concern with financial sustainability has not only dominated almost all recent local government conferences across Australia, but it has also formed the capstone of several public inquiries into state local government systems. For instance, at the state level, both the South Australian Financial Sustainability Review Board's (FSRB) (2005) Rising to the

\footnotetext{
1 The authors would like to thank two anonymous referees for helpful comments on an earlier draft. Address for correspondence: bdollery@une.edu.au
} 
Challenge and the Independent Inquiry into the Financial Sustainability of NSW Local Government' s (LGI) (2006) Are Councils Sustainable were centrally occupied with determining the meaning of financial sustainability in Australian local government and developing measures of financial sustainability. Moreover, the Queensland Local Government Association (LGAQ) (2006) Size, Shape and Sustainability (SSS) program, the Western Australian Local Government Association (WALGA) (2006) Systemic Sustainability Study and the Local Government Association of Tasmania (LGAT) (2007) Review of the Financial Sustainability of Local Government in Tasmania had at their core the problem of assessing financial sustainability in their respective local government systems.

Similarly, at the national level, a commissioned report by PriceWaterhouseCoopers (PWC) (2006), entitled National Financial Sustainability Study of Local Government, considered the problem of financial sustainability across all Australian local government jurisdictions. In an analogous vein, the Productivity Commission (2008) examined the revenue-raising capacity of Australian local government. In addition to these efforts, an embryonic Australian academic literature exists (see, for example, Murray and Dollery, 2005; 2006; Walker and Jones, 2006; Dollery, 2006).

Dollery and Crase (2006) have scrutinized the contemporary debate on financial sustainability in Australian local government. Various salient conclusions were drawn from their analysis. In the first place, no agreed definition of financial sustainability existed in Australia. Secondly, recent attempts at determining the financial sustainability of local councils had considered quite different aspects of the monetary situation of municipalities; this served to further underline the lack of national consensus on the meaning of financial sustainability. Thirdly, whereas the South Australian, New South Wales, Queensland, Western Australian, Tasmanian and PWC investigations into financial sustainability all employed Key Performance Indicators (KPIs) (most commonly in the form of financial ratios), Dollery and Crase (2006) have identified numerous problems with the KPI method of performance appraisal, including the fact that the observed incidence of local government failure bears little statistical relationship to KPI scores, at least in the New South Wales local government milieu (see Murray and Dollery 2005). It thus follows that policy makers should 
be very wary of making far-reaching decisions based upon disputed definitions of financial sustainability as well as flawed KPIs with poor predictive capacity.

Quite apart from the doubt surrounding the meaning and measurement of financial sustainability, a second important question that must be taken into account deals with the 'non-financial' aspects of sustainability in local government. This question has been at least partially explored in other comparable national contexts, where local government sustainability has been discussed in somewhat more holistic terms than mere financial sustainability. For example, while the initial brief of the Lyons Inquiry into Local Government in England required it to 'search for a sustainable solution to the problems of local government finance' (Lyons, 2005, 3), the Inquiry stretched its ambit to include (i) the strategic role of local government; (ii) devolution and decentralisation; (iii) managing pressure on local services and (iv) scope for new agreement between central and local government (Lyons, 2005, 7-10). Grant and Dollery, (2011) have argued that the Inquiry's subsequent recommendations, and especially 'place-shaping' (Lyons, 2007) amounted to a revitalised theory of local government which has been reflected in the Cameron Government's Localism Bill (2010) (see, for example, CLG, 2010). Financial sustainability embraced local governments' own revenue-raising capacity, but also included sustainable community strategies where sustainability is context-dependant (see, for example, Lyons, 2007, 11) and where 'lifestyle sustainability' is based upon alleviating pressure on the environment (see, for example, Lyons, 2007, 69).

In the New Zealand the Report of the Local Government Rates Inquiry (2007), entitled Funding Local Government, initially defined sustainability according to terms derived from the Government's Fiscal Responsibility Act (1994) or what it described as 'the affordability of expenditure and equity of funding over the long term', noting that 'in general, local government is paying insufficient attention to these issues' (Rates Inquiry, 2007, 3) and incorporating 'environmental sustainability' into its recommendations.

Against this comparative international context, in this paper we pursue the question: aside from direct financial considerations, what other factors determine the broader long-run 
sustainability of Australian local councils? In other words, can we identify 'overall' local government sustainability and define its characteristics?

The paper itself is divided into three main parts. Section 2 considers the problem of defining adequately council sustainability and identifying the chief determinants of this broader conception of local government sustainability. Section 3 examines each of the three main putative attributes of community or social sustainability in local government advanced in section 2 and seeks to illustrate how the current LGAQ (2006) Size, Shape and Sustainability (SSS) program and the WALGA (2006) Systemic Sustainability Study have addressed these attributes. The paper ends with some brief concluding remarks in section 4 .

\section{Defining Overall Council Sustainability}

\section{Generic sustainability}

The concept of sustainability first emerged in the development literature through the work of the World Commission on Environment and Development ('Brundtland Commission') (1987: 8), which defined sustainable development as a process that 'meets the needs of the present without compromising the ability of future generations to meet their own needs'. A key element of this definition lay in its conflation of environmental concerns with economic growth which had previously been juxtaposed (Romero-Lankao, 2000). As a consequence, the Brundtland Commission (1987) definition was rapidly adopted by a wide range of writers since it served as a unifying umbrella term for a diversity of perspectives on development. However, the consensual nature of this definition came at the price of ambiguity and imprecision (Adger and Jordan, 2009; Leuenberger and Bartle, 2009), which has now fragmented into 'dozens of definitions [that] are being passed around among experts and politicians, because many and diverse interests and visions hide behind the common keyidea' (Sachs, 1995: 8).

The disintegration of the earlier general consensus on the meaning of sustainability into a raft of conflicting and frequently value-laden streams of thought is evident in its application to local government. This should not be surprising given the complex multi-dimensional nature of local government with its democratic, economic, environmental, and social role in local service provision and local community life. Nonetheless, the fact that there is currently no 
satisfactory universal definition of sustainability in local government is unfortunate because explicit recognition of sustainability forces local government policy makers to give weight to the future consequences of current decisions. It is thus worth exploring the nature of sustainability in the local government environment.

In this paper, we propose that the concept of local government sustainability should extend beyond the narrow confines of financial sustainability or financial viability to include the vibrancy of local democracy, local social capital and local council administrative and technical capacity. In this sense, sustainability is taken to broadly refer to the ability of a local authority to function effectively over the long term. However, we do not embrace environmental concerns directly since local government seldom has the legislative authority to make a decisive contribution to long-run environmental sustainability nor does environmental sustainability itself have an uncontested meaning.

\section{Tensions between democracy and efficiency}

In common with the conceptual and factual difficulties of defining financial sustainability, the problem of defining overall council sustainability presents similar analytical challenges. In all Westminster-style advanced democracies, local government plays a dual role. Aulich (2005, p.198) has described this twin function in Australian local government in some detail. In the first place, local government 'provides a voice to local aspirations for decentralized governance'. What can be termed the 'local democracy approach' thus places fundamental value on 'local differences and system diversity' and encourages directed activities and policy reforms aimed at improving 'local choice and local voice'. This is premised on the notion that a local council 'can and will make choices that will differ from those made by others'. According to this view, 'a premium is placed upon traditional democratic values' that fully embrace 'access', 'accountability', 'representativeness' and 'responsiveness' (Stewart 1997). The 'vibrancy' of local democracy thus becomes a desired outcome in its own right.

In addition to these attributes of the local democracy approach, it is possible to identify other dimensions that may be important. In this respect, the concept of 'social capital' is crucial. First conceived by Coleman (1988) and later popularized by Putnam (1993), social capital refers to those features of social life that enable participants to act together more effectively 
to pursue shared objectives. In the local government context, social capital engenders local civic awareness that manifests itself in a variety of community projects, ranging from the formation of local social associations and sports clubs to local business initiatives. The determinants of local social capital are complex and not well understood (Quibria 2003), but include a 'sense of community' and a 'sense of place' that derive from living in a small and distinctive community, such as a local government area. Community size and community social capital are therefore intrinsically linked together.

The local democracy approach necessarily implies support for "collaborative or pluralist processes of reform' rather than top-down 'technocratic' policy intervention that overrides local opinion (Aulich 2005). Rather than being viewed as a burdensome financial impost on the local exchequer, representative local government is seen as a worthy policy goal on its own merit. The costs associated with local governance, including local elections, consultation processes, 'democratic audits', community participation, elected councillors, their supporting secretariat and the whole gamut of local democratic autonomy, can thus be justified in the same way as financial outlays on any other bona fide council service. Accordingly, public policy should not simply seek efficient service local provision, but also effective local democracy. Political process becomes as important as economic outcome. The result is an emphasis on 'bottom-up' local consultation and local policy formulation.

The second primary role of local government in a Westminister-type democratic constitutional system focuses on local councils as 'a mechanism for [the] efficient delivery of local services to local communities' (Aulich, 2005, p.199). In terms of this perspective, in its role as a provider of local public and quasi-public goods and services, local government must focus on efficient service delivery above all else (Tucker 1997). In other words, local government is not regarded as a representative entity in its own right, but rather as an instrument for meeting local needs through local services in the most cost effective manner possible. This instrumentalist conception of the role of local government in a federal system thus stresses the importance of policy reform aimed exclusively at enhancing the efficiency of local government, regardless of the impact this might have on the vibrancy of local democracy. Put differently, in the instrumentalist service provision approach 'fiscal and economic issues override other social and political concerns' and 'tradition-bound or valueorientated forms of political and social organization are replaced by purely instrumentally 
rational institutions' (Aulich, 2005, p.199). Economic outcomes thus take precedence over political processes.

The main policy implications of this 'local service delivery approach' have been described by Aulich (2005, p.199). First, the policy goals of operational efficiency and overall economy are pursued by state government intervention into local government. Second, this intervention often generates legislative and regulatory criteria aimed at uniformity in processes and outcomes at the local level. Third, as a consequence, participatory and deliberative processes are devalued, 'with top-down technocratic processes being more typical' (Aulich, 2005, p. 199).

Obvious tensions exist between the two primary roles of local government in a Westminister-style democratic polity and these are perhaps best exemplified in the diametrically opposed policy implications that derive from the local democracy approach and the local service approach. Steyvers, et al. (2006, p.429) draw a distinction between 'input legitimacy' and 'output legitimacy' to highlight this tension. Input legitimacy rests on 'responsive government' that can be achieved by 'integrating citizens and providing space for participatory input' into municipal decision-making. By contrast, output legitimacy occurs through providing 'effective and efficient public services'. This dichotomy can be illustrated by means of Figure 1:

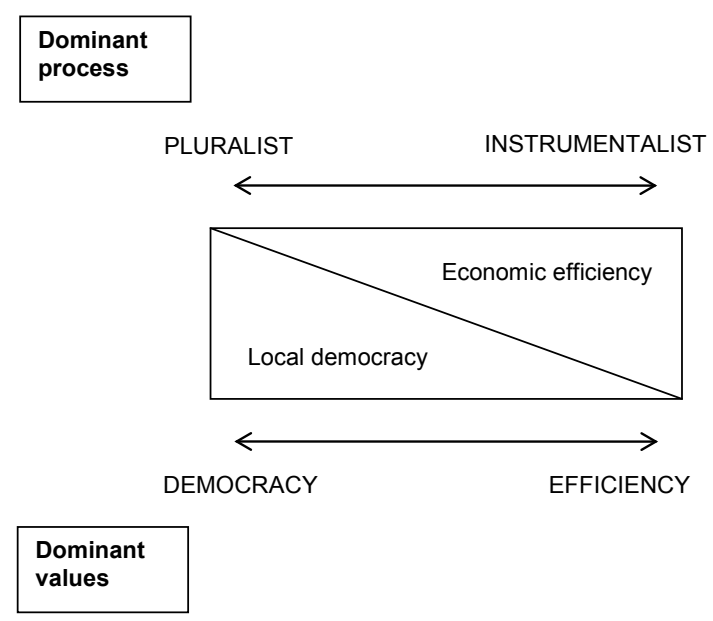

Figure 1. Competing Roles of Australian Local Government Source: Adapted from Aulich (1999, p.20). 
Figure 1 depicts the opposing value systems and associated process orientation of the local democracy approach and the local service approach. The instrumentalist policy preference of the local service approach is manifest in its end-state objective of achieving greater cost effectiveness regardless of the price paid in terms of democratic process. For example, if local democratic processes express community preferences for small 'close-to-the-people' local councils, even if this may involve relatively more expensive service provision, then 'top-down' state government intervention in the form of forced amalgamation, or other kinds of obligatory structural change, is justified if it can deliver cheaper services. By contrast, if due democratic process embodies full public participation, even where this may entail the provision of redundant additional services or more costly local services, then this is warranted under the local democracy approach since it expresses legitimate community preferences.

Whereas Aulich (2005) sets the local democracy approach and the local service approach in juxtaposition as competing and almost mutually exclusive roles for Australian local government, it is possible to identify aspects of both positions that contain overlapping and mutually reinforcing (or mutually destructive) dimensions of contemporary local authorities. If we consider a hypothetical case where an enforced local government merger of several small councils with a single large municipality in a regional spatial setting would generate an aggregate reduction in the per capita costs of service provision across the entire new amalgamated entity, and this merger will necessarily mean that council activities and employment are geographically reallocated away from the previous small councils towards the dominant large municipality, then feedback loops between local democracy approach and the local service approach become apparent. For instance, small country councils are often a major employer in small rural towns. If council employees are forced to work in the former large council area in the new amalgamated structure, then this will set in motion powerful negative multiplier effects that can lower population, reduce economic activity, and threaten the viability of other public and private services, like public schools and banking facilities.

Secondly, if we invoke attributes of the local democracy approach neglected by Aulich (2005), such as the historically, psychologically and sociologically crucial concepts of 'sense of community' and 'sense of place', that form an important part of the social capital of small 
country towns, then this will also have substantial economic effects. After all, a municipal council often represents the 'heart' of a community and serves to symbolize its character and independence. The abolition of these councils could thus severely damage a 'sense of community' built up over the generations. The economic consequences of this loss may be felt in different retail shopping patterns, altered school enrolment, changed sporting club allegiances, and so forth, which will have ramifications for the composition of economic activity and the strength of the rate base of the former small council areas.

Finally, and perhaps most importantly, process and outcome are inextricably linked through democratic representation in local government. Thus, the merger of small councils with a larger municipality can have obvious and severe resource implications for residents of the small merged towns. For example, if a previously autonomous local council is compulsorily amalgamated with a larger, adjacent regional centre, then its elected representation automatically falls as a proportion of all councillors. This may mean relatively fewer resources will be directed towards the needs of residents of the small councils relative to their counterparts living in the dominant larger regional city. Moreover, where service provision preferences differ between the citizenry of small and large councils, the pattern of service provision can also shift to the detriment of residents of small towns. These effects will be even more acute if electoral wards are abolished since this may mean no representation at all for minority ratepayers living in sparsely populated areas on the outskirts of the new local government structure.

In essence, the local democracy approach and the local service approach can thus overlap in some respects and this affects the nature of trade-offs between the two perspectives. In other words, single-minded pursuit of economic gain regardless of political process can have the unintended effects of reducing the aggregate economic benefits through the spatial redistribution of economic activity and council service operations within the new amalgamated entity. Political process thus cannot be entirely divorced from economic outcome.

The tensions between input legitimacy and output legitimacy, stressed by Steyvers, et al. (2006), has focused attention on the need to reconcile these two imperatives. Some scholars 
have pursued this line of inquiry, including Kersting and Vetter (2003), and have sought to close the 'gap' between service efficiency and participatory democracy. However, the fruits of this debate have yet to appear.

\section{Community sustainability}

The identification of two contending primary roles for Australian local government by Aulich (2005), and the augmentation of this dichotomized approach with the recognition that in some respects outcome and process are inextricably linked (since service efficiency cannot be considered as entirely discrete from service distribution), can shed considerable light on the problem of local government sustainability. We have already very briefly considered the thorny question of 'financial sustainability' - a critical component of the local service approach. But what are the chief elements of 'community sustainability' (as distinct from financial sustainability) that comprise the essence of the local democracy approach?

Several clusters of factors suggest themselves. The first constellation of attributes will centre on the vibrancy of local democracy in the sense that it engages maximum public participation. Local democratic processes obviously play a central role in overall council sustainability and these include democratic 'access', 'accountability', 'representativeness' and 'responsiveness' outlined by Aulich (2005).

The second cluster of attributes revolves around local social capital and its relationship with local councils. Although little is known about the genesis of social capital, it seems to spring from a well-developed 'sense of community' and a 'sense of place' that flow from living in a small community whose members interact frequently. While these abstract and somewhat 'ethereal' factors are very difficult to measure, this obviously does not diminish their importance.

The third constellation of factors that influence local government sustainability focuses on the capacity of local government. Local government cannot command the respect of its constituents if it is unable to effectively formulate agreed policy positions and implement these decisions into concrete action. The capacity of local government thus has two dimensions: Well-functioning elected leadership and sufficient administrative and technical expertise. These two attributes of local government capacity are crucial to council 
sustainability. In the first place, there must be effective functioning of an elected council free of personal rancour and disruptive factionalism. Although the Australian literature has not addressed this aspect of local councils empirically, anecdotal evidence suggests that dysfunctional elected councils are the single most important cause of local government failure in New South Wales local government. This is hardly surprising since efficacious and cooperative elected councils represent the bedrock of 'local choice and local voice' that underpin local government leadership.

Each of these elements will now be considered in greater detail. Amongst other things, we will consider the problem of how these attributes are tackled by the LGAQ's (2006) Size, Shape and Sustainability program and the WALGA (2006) Systemic Sustainability Study by way of illustrative examples. It must be stressed that since almost nothing has been written on this question in the literature on Australian local government, the discussion is exploratory and the conclusions tentative.

\section{Factors Influencing Overall Local Government sustainability}

The three constellations of factors identified above should not be regarded as definitive. With this caveat in mind, we now consider each cluster in turn.

\section{Vibrancy of Local Government Democracy}

Scholars of local government have charted a steady transformation in the nature of government within the local sector over the past decade. The term 'governance' attracted increased scrutiny in the 1990s (see, for example, Stoker, 1998) and has been used to describe the new relationship between government and the governed that emphasizes 'steering' and not 'rowing'. Unfortunately, a confusing array of meanings has been attached to the term. In the present context, we adopt the definition advanced by Goodin (1996, p.7) in which governance represents 'nothing less than the steering of society by officials in control of what are organizationally "the commanding heights" of society'.

Another way of approaching governance was formulated by Keohane and Nye (2000, p. 37): 'by governance we mean the processes and institutions, both formal and informal, which guide and restrain the collective activities of a group'. Thus 'government is the subset that acts with authority and creates formal obligations'. However, governance is not the exclusive 
domain of governments themselves, but also involves private organizations, nonprofit institutions, and a host of other social structures.

Denters and Rose (2005, p.6) have characterised the new relationship between local government and its various client groups as involving a 'dual challenge': An increase in citizen involvement has required local authorities to 'improve their capacity for effective and efficient governance', prompting local governments to search for innovative ways to meet these demands, including turning to citizens and community groups in the search for innovation and problem-solving. However, at the same time, the decline in party-political links into councils has required the implementation of different avenues for decision-making and citizen involvement. Denters and Rose (2005, p.6) labelled these different types of involvement 'new forms of local democracy'.

Developing operational measures of the vibrancy of local democracy presents immense conceptual problems that obviously cannot be resolved in the exploratory conjectural context of the present paper. However, if we consider the deliberations of two recent inquiries into Australian local government systems, then this at least serves to highlight not only the implicit importance of local democracy, but also provides at least some idea of the flavour of the discourse on local democracy in contemporary Australian local government.

The Systemic Sustainability Study produced under the auspices of the WALGA (2006, p.1/2) stressed the importance of 'good governance'. It defined this quality as 'the ability of local government to operate with integrity and to assure the community that efficient and effective management is applied in the community interest'. In the Western Australian context, the Report argued that 'good governance' had not always been manifest in that state, especially insofar as 'large intergenerational equity transfers' in asset management had taken place and the general competence powers in the Western Australian Local Government Act had not been fully understood. However, apart from these issues, the Systemic Sustainability Study did not provide any indicators to measure this attribute of local government.

The Queensland Size, Shape and Sustainability Guidelines Kit (LGAQ, 2006, Chapter 3) does provide some implicit measures of good governance. For instance, Indicator Category 4 
deals with 'standards of governance' and proposes two indicators. 'Decision Making and Management' seeks to measure three formal aspects of the 'level of competence' of a given council: 'Corporate planning'; 'risk management'; and 'delegations' (p.20). In a similar vein, 'Accountability' concerns itself with 'how a council accounts for its key activities and what systems and processes are in place to support this accountability' (p.21). Two separate indicators are put forward to gauge this kind of 'accountability': 'Performance management' as measured by the performance management process in place; and the 'internal audit process' as captured by the nature of the internal audit process.

It could also be argued that the Size, Shape and Sustainability Guidelines Kit (LGAQ, 2006, Chapter 3) contains some other measures that indirectly touch on good governance. For example, Indicator Category 3 focuses on 'planning'. Two specific indicators are outlined: 'Service coordination and efficiency' which considers the question of whether 'key infrastructure' is 'coordinated' and yields 'efficient services' (p.18); and 'growth management' that attempts to gauge 'how well a council is able to respond to and manage population growth impacting on its area' (p.19).

Finally, the Size, Shape and Sustainability Guidelines Kit (LGAQ, 2006, Chapter 3) may gather information with a bearing on public participation under Indicator Category 2 that deals with 'community of interest'. 'The performance indicator 'community engagement' tries to evaluate 'how well a council engages with it's community' (p.17) and suggests the use of 'existing community surveys', 'current community engagement plans', and the 'community complaints register'. It should be noted that all three sources of information represent formal processes and thus act as proxy variables for 'real' or informal engagement.

\section{Local Social Capital and Local Government}

The concept of social capital is based on the notion that 'social interaction matters' since it 'creates social networks, fosters trust and values, sustains norms and culture and creates community' (Quibria, 2003, p.19). Coleman (1990, p.302) conceived of social capital as analogous to 'other forms of capital' because it makes 'possible the achievement of certain ends that would not be attainable in its absence'. In much the same vein, Putnam (1993, p.7) defined social capital as 'features of social organization, such as trust, norms, and networks, that can improve the efficiency of society by facilitating coordinated actions'. 
The key components of social capital identified by all these scholars are 'networks of civic engagement', 'norms of generalized reciprocity', and 'relations of social trust'. Quite apart from the significance of social capital for economic development and social integration, it also has important public policy implications for local government. Various mechanisms have been proposed that link the performance of local councils to social capital. In the first place, Putnam (1993) argued that municipal performance may be enhanced by high levels of social capital since it encourages greater monitoring of the behaviour of council officials. This process occurs directly because council employees care about their reputations with people among whom they interact frequently. It also occurs indirectly because monitoring council performance is a public good and thus prone to the well-known free rider problem in collective action; social capital assists in overcoming free riding.

If Putnam (1993) is correct in identifying informal performance monitoring as the link between local government performance and social capital, then what are the policy implications of this view for local government? We have seen that social capital is likely to be high when people interact frequently with each other. Moreover, the reputational impact of monitoring by people who have regular dealings with the council employees in question will be stronger than in the case of comparative strangers. It follows that small councils in small local government areas characterized by small populations will be the most effective in fostering social capital, frequent interaction between council workers and elected representatives and the public, and thereby more efficacious monitoring of council performance.

A second mechanism that may link social capital to the performance of municipalities was suggested by Putnam (1993; 2000), Aarts (1995) and other scholars. It is argued that various factors, especially increased urbanization, have contributed to a decline in organizational participation by citizens. This in turn has led a reduction in the linkages between the public and local authorities and altered the relationship between the two for the worse. Unfortunately, little is known about the empirical attributes of social capital and therefore on appropriate policy responses to increase social capital. However, some work has been done on this aspect of social capital. For instance, in Bowling Alone, Putnam (2000) established 
evidence that points to a decline in social capital in the United States over the past three decades. Similarly, Knack and Keefer (1997) found that social capital is a measurable determinant of economic performance in international terms.

In addition to this international empirical literature on social capital, some Australian work has focused on social capital in regional and rural communities that can shed at least some light on the question. For instance, Woodhouse (2006) conducted a comparative study of two anonymous 'regional towns' and found that high levels of social capital facilitated local economic development and this process can best be stimulated by policy measures aimed at integrating these communities with broader partnerships and policy debates. Other Australian scholars, including Onyx and Bullen (2000), Sobels, Curtis and Lockie (2001) and Leigh (2006), have arrived at analogous conclusions. However, to the best of our knowledge unfortunately no Australian study has focused exclusively on the relationship between effective local councils and social capital.

The empirical basis for policy formulation on local government and social capital is thus very limited. This necessarily means that any policy proposals must be speculative. But it does seem clear that small communities in small local government areas are best placed to engender high levels of social capital since interaction between citizens and local government representatives and employees will be higher under these circumstances. Furthermore, it is highly likely that a well-developed 'sense of community' and a 'sense of place' will be most pronounced in small local government areas where people are acquainted with a relatively high proportion of their fellow citizens.

What implications do these speculative hypotheses have for local government reform in general aimed at enhancing sustainability? Consider the example of the Queensland Size, Shape and Sustainability program. The Guidelines Kit (LGAQ, 2006, pp.6-7) prescribed four 'options for change' that could be followed by local councils: 'Resource sharing through service agreements'; 'resource sharing through joint enterprise'; 'significant boundary change'; and the 'merger/amalgamation of adjoining councils'. The last two of these options involve modification to the size, shape and population of an affected local government area and thereby could influence adversely both the 'sense of community' and a 'sense of place' 
among residents. In this respect, these two options might serve to reduce social capital, damage the associated monitoring aspect of social interaction, and thus impair the efficacy of local government. Since both forms of resource sharing leave the boundaries and population of a participating local council intact, it can be argued that they would leave both the 'sense of community' and a 'sense of place' untouched.

\section{Local Government Capacity}

In section 2, it was argued that local government capacity had two separate dimensions. Firstly, the political capacity derived from the democratic legitimacy and effective decision making abilities of elected representatives comprising local councils. Although no comprehensive empirical research has yet been undertaken in Australian local government, anecdotal evidence suggests that the primary cause of the failure and ultimate dissolution of local councils by state governments lies in dysfunctional elected councils rather than financial distress and other problems. Where councils are plagued by bitter personal animosities, 'infighting' between councillors, intransigent factionalism, and disruptive meetings, 'policy gridlock' typically occurs that can effectively stall the smooth running a local authority. A secondary effect of dysfunctional elected councils resides in the loss of public confidence in their elected representatives and a diminution of collaborative partnerships between community organizations and local government. In other words, the most important element in local government sustainability can be found in cooperative functional elected bodies.

It follows that any attempt to assess the long-run viability of local authorities should first establish whether sound relations exist between both mayors and elected councillors and amongst elected representatives themselves. In practice, this can only be established by observing the workings of council meetings and the relationships between elected representatives. No abstract performance indicator can replace observation and judgment.

The Systemic Sustainability Study (WALGA 2006) stressed the importance of effective and cohesive elected councils. It emphasized the key role of 'leadership capacity' by observing that 'the experience, competence, and passion of elected members' is essential 'to represent the desires and aspirations of local communities' (WALGA, 2006, p.2). However, no definite statistical measures were proposed to assess empirically these attributes. 
The administrative and technical ability of council staff forms the second dimension of local government capacity. The importance of this type of council capacity can hardly be overstated. In this regard, Dollery, Crase and Johnson (2006, p.148) made the following observation: 'A proposition sometimes advanced in the Australian debate over amalgamation is that larger councils tend to have greater levels of administrative and other expertise, in part due to the fact that their size permits the employment of specialist skills that cannot be readily acquired by smaller municipalities'. But they hasten to add that while this argument has 'considerable merit', partnership agreements between small councils can achieve the same outcome in terms of acquiring specialist skills.

The Systemic Sustainability Study (WALGA, 2006, p.2) also underlined the importance of the capacity of local government employees to the efficient functioning of local councils. Insufficient administrative capacity in Western Australia had resulted in two identifiable problems. Firstly, 'innovation' had occurred in the local government sector in that state, but had not been implemented 'from a systematic perspective'. Secondly, 'asset management practice' was unsatisfactory and had masked 'exposures for communities and councils'.

The question of whether or not an individual council is sustainable by virtue of its administrative and technical expertise can only be settled with certainty by empirical examination of staffing levels relative to need. In this sense, local government administrative capacity is amenable to measurement through selected performance indicators. For instance, an informative ratio could compute the proportion of vacancies for professional and technical staff. This would provide a simple and robust statistic that would allow for comparisons between different councils.

By contrast, the Size, Shape and Sustainability Guidelines Kit (LGAQ, 2006, Chapter 3) did at least attempt to provide measurable estimates of council sustainability in human resources. For example, the 'Human Resourcing' indicator considered various factors, such as 'staff turnover rates'. 


\section{Concluding Remarks}

It has been argued that not only does 'financial sustainability' have no agreed meaning in Australian local government, but also it represents only a single dimension of overall council sustainability (Dollery, Byrnes and Crase, 2007). Indeed, anecdotal evidence suggests that the primary cause of local government failure lies in 'infighting' in elected councils and related 'policy gridlock'. This means that an accurate assessment of aggregate 'overall sustainability' in local government must also include other attributes of contemporary local authorities.

Apart from the intractable difficulties in determining financial sustainability, two main problems have been identified with evaluating overall local government sustainability. In the first place, the abstract and ephemeral nature of the concept of overall sustainability makes it hard to define with any degree of precision. Many factors clearly play an important role: Local government democracy; local government capacity; 'sense of place'; community sustainability; local social capital; local preference diversity; local leadership; and local economic development all seem relevant.

In this paper, we have argued that three main 'clusters' of attributes of overall local council sustainability seem apposite: The 'vibrancy of local democracy' that has become even more essential in the new local governance paradigm; 'local social capital' that can enhance the good working of effective local authorities; and 'local government capacity' in both the political and technical aspects of local governance. However, given the exploratory nature off the analysis, this tripartite classification may not be exhaustive. Other factors could also easily be included, perhaps most notably 'environmental sustainability'.

However, an obvious constraint on the inclusive of a large 'wish list' of additional attributers of overall sustainability is the extent of council control over these factors. For example, in the Australian federal system of government, several functions formally handled by local government are in fact strictly governed by state and Commonwealth regulation and their effective discharge is often determined by finance controlled by these higher tiers of government. Local government thus has little discretionary power of these functions, 
regardless of how well it operates. It is therefore misplaced to seek to embrace attributes of overall sustainability that councils cannot influence and then evaluate councils on this basis.

The existence of restrictions imposed on local government by higher tiers of government is by no means limited to Australia. Indeed, almost all local government systems, in developed and developing countries alike, face legislative and other constraints which confine policy latitude. This problem seems especially acute in the realm of finance, where restrictions on taxation powers and borrowing authority are commonplace (see, for instance, Shah 2006a; 2006b).

A second constraint on the determination of overall local government sustainability resides in the thorny problem of measurement. The three clusters of overall sustainability proposed in this paper - the 'vibrancy of local democracy', 'local social capital' and 'local government capacity' - cannot be measured directly. This means that proxy variables must be used to try to capture key elements of these clusters and none of these variables is exact. It follows that subjective judgment and inference are unavoidable.

Despite the obvious need to evaluate local government sustainability from a broader perspective than simply financial sustainability, these two problems seem to have deterred some earlier state local government sustainability investigations from adopting this wider perspective. As Dollery and Crase (2006) have shown, both the South Australian Financial Sustainability Review Board's (2005) Rising to the Challenge and the Financial Sustainability of NSW Local Government' s (2006) Are Councils Sustainable paid lip service to the importance of overall sustainability, but did not attempt to assess it in their work. By contrast, to their credit, the ill-fated LGAQ's (2006) Size, Shape and Sustainability program and the WALGA (2006) Systemic Sustainability Study: In Your Hands - Shaping the Future of Local Government in Western Australia did at least recognize that financial sustainability alone is insufficient. However, as we have attempted to demonstrate, much remains to be done. 


\section{References}

Aarts, K 1995, 'Intermediate organizations and interest representation', in H. D. Klingeman and D. Fuchs (eds.), Citizens and the State, Oxford, Oxford University Press, pp. 227-257.

Adger, WN and Jordan, A (eds) 2009, Governing Sustainability, London: Cambridge University Press.

Aulich, C 1999, 'From convergence to divergence: reforming Australian local government', Australian Journal of Public Administration, vol. 58, issue 1, pp. 12-23.

Aulich, C 2005, 'Australia: still a story of Cinderella', in B. Denters and E. Rose (eds.), Comparing Local Governance: Trends and Developments, Basingstoke: Palgrave Macmillan pp. 193-210.

CLG (Department for Communities and Local Government [UK]) 2010, A Plain English Guide to the Localism Bill. Accessed 19 May 2011 <http://www.communities.gov.uk/documents/localgovernment/pdf/1818597.pdf >

Coleman, JS 1988 'Social capital in the creation of human capital', American Journal of Sociology, vol. 94, issue 1, pp. 95-120.

Coleman, JS 1990, Foundations of Social Theory, Cambridge, Harvard University Press.

Denters, B. and Rose, LE 2005, 'Local governance in the third millennium: a brave new world?' in B. Denters and L. E. Rose, Comparing Local Governance. Trends and Developments, Government beyond the Centre, Basingstoke, Macmillan, pp. 1-11.

Dollery, BE 2006, 'An alternative approach to identifying councils 'at risk': a rejoinder to Bob Walker and Stewart Jones', Economic Papers, vol. 25, issue 4, pp. 358-361.

Dollery, BE, Byrnes, JD. and Crase, 2007, 'Too Tough a nut: determining financial sustainability in Australian local government', Australasian Journal of Regional Studies, vol. 13, issue 2, pp. 110-133.

Dollery, BE and Crase, L 2006, 'A comparative perspective on financial sustainability in Australian local government', Working Paper 01-2006, Centre for Local Government, University of

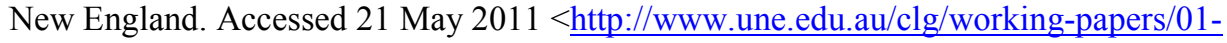
2006.pdf>

Dollery, BE, Crase, L and Johnson, A 2006, Australian Local Government Economics, Sydney, University of New South Wales Press.

FSRB (Financial Sustainability Review Board) 2005, Rising to the Challenge, South Australian Local Government Association, Adelaide.

Goodin, R 1996, The Theory of Institutional Design, Cambridge: Cambridge University Press.

Grant, B and Dollery, BE 2011. 'Political geography as public policy? 'Place-shaping' as a mode of local government reform, Ethics, Policy and Environment, vol. 14 issue 2, pp. 1-17.

Keohane, R and Nye, J (eds.) 2000, Governance in a Globalized World, Washington, Brookings Institute.

Kersting, N and Vetter, A 2003 (eds.), Reforming Local Government in Europe: Closing the Gap between Democracy and Efficiency, Opladen, Leske and Budrich.

Knack, S and Keefer, P 1997, 'Does social capital have an economic payoff? a cross-country investigation', Quarterly Journal of Economics, vol. 72, issue 4, pp.1250-1281.

Leigh, A 2006, 'Trust, inequality and ethnic heterogeneity', Economic Record, vol. 82, issue 258, pp.268-280.

(LGI) (Independent Inquiry into Local Government Inquiry) ('Allan Report') 2006, Are Councils Sustainable? Final Report: Findings and Recommendations, Sydney, NSW Local Government and Shires Association. 
LGAQ (Local Government Association of Queensland) (2006) Size, Shape and Sustainability (SSS) Program Guidelines Kit, Brisbane, Local Government Association of Queensland.

LGAT (Local Government Association of Tasmania) (2007) Review of the Financial Sustainability of Local Government in Tasmania, prepared by Access Economics. Accessed 21 May 2011 $<$ http://www.lgat.tas.gov.au/webdata/resources/files/Access_Economics_final_report_21.pdf $>$

Leuenberger, DZ and Bartle, JR. 2009, Sustainable Development for Public Administration, New York, M.E. Sharpe.

Lyons Inquiry into Local Government 2007, Place-shaping: A Shared Ambition for the Future of Local Government, London, Stationary Office. Accessed 21 May 2011 $<\underline{\text { http://www.official- }}$ documents.gov.uk/document/other/9780119898552/9780119898552.pdf $>$

Lyons Inquiry into Local Government (2005) Consultation Paper and Interim Report, London, Stationary Office. Accesses 21 May $2011<$ http://www.webarchive.org.uk/wayback/archive/20070428120000/http://www.lyonsinquiry .org.uk/docs/051215\%20interim\%20report.pdf $>$.

Murray, DR. and Dollery, BE 2005, 'Local government performance monitoring in New South Wales: are 'at risk' councils really at risk?', Economic Papers, vol. 24, issue 4, pp.332-345.

Murray, D.R. and Dollery, BE 2006, 'An evaluation of performance measurement and the identification of "at risk" municipal councils in NSW local government', Public Administration Today, vol. 6, pp.46-61.

Onyx, J and Bullen, P 2000, 'Sources of social capital', in I. Winter (ed.), Social Capital and Public Policy in Australia, Melbourne, Australian Institute of Family Studies, pp.105-135.

PriceWaterhouseCoopers 2006, National Financial Sustainability Study of Local Government, Sydney, PriceWaterhouseCoopers.

Productivity Commission (2008), Assessing Local Government Revenue-Raising Capacity, Melbourne, Productivity Commission.

Putnam, R 1993, Making Democracy Work: Civic Traditions in Modern Italy, Princeton, Princeton University Press.

Putnam, R 2000, Bowling Alone: The Collapse and Revival of American Community, New York, Simon and Schuster.

Quibria, MG 2003, 'The puzzle of social capital', Asian Development Review, vol. 20, issue 2, pp. 19-39.

Rates Inquiry (Report of the Local Government Rates Inquiry[New Zealand]), 2007 Funding Local Government, Department of Internal Affairs. Accessed 21 May 2011 $<$ http://www.dia.govt.nz/Pubforms.nsf/URL/RatesInquiryFullReport.pdf/\$file/RatesInquiry FullReport.pdf $>$. Consulted 19 May 2011

Romero-Lankao, P 2000, 'Sustainability and public management reform. Two challenges for Mexican environmental policy'. The American Review of Public Administration, vol. 30, issue 4, pp. 389-399.

Sachs, W 1995, The Political Anatomy of 'Sustainable Development', Wuppertal: Wuppertal Papers.

Shah, A 2006a, Local Governance in Developing Countries. Washington, D. C: World Bank.

Shah, A 2006b, Local Governance in Industrial Countries. Washington, D. C: World Bank.

Sobels, J, Curtis, A and Lockie, S 2001) 'The role of Landcare networks in Australia: exploring the contribution of social capital', Journal of Rural Studies, vol. 17, issue 3, pp. 265-276.

Stewart, J 1997, 'The governance of difference', in M. Chisholm, R. Hale and D. Thomas (eds.), A Fresh Start for Local Government, London, Public Finance Foundation, pp. 65-78. 
Steyvers, K, Reynaert, H, De Cuerninck, C and Valckew, T 2006, 'Mayors in governance: heading for efficiency and democracy’, Local Government Studies, vol. 32, issue 4, pp. 429-446.

Stoker, G. 1998 'Governance as theory: five propositions', International Social Science Journal, vol. 50 , issue 15 , pp. 17-28.

Tucker, D 1997, 'From administration to management' in BE Dollery and NA Marshall (eds.), Australian Local Government: Reform and Renewal, Melbourne, Macmillan, pp. 69-88.

Walker, R and Jones, S 2006, 'An alternative approach to identifying councils "at risk", Economic Papers, 25(4), pp. 347-357.

Western Australian Local Government Association (WALGA) (2006), Systemic Sustainability Study: In Your Hands - Shaping the Future of Local Government in Western Australia, Interim Report, Perth, Western Australian Local Government Association.

Woodhouse, A 2006, 'Social capital and economic development in regional Australia: case study', Journal of Rural Studies, vol. 22, issue 1, pp. 83-94.

World Commission on Environment and Development ('Brundtland Commission') 1987, Our Common Future, London: Oxford University Press. 